\title{
Passagens de Antiguidade Romana ao Ocidente Medieval: leituras historiográficas de um período limítrofe
} José D'Assunção BARROS •

\begin{abstract}
Resumo: Este artigo busca examinar algumas interpretações e perspectivas sob as quais se pode ou tem sido examinada a questão da passagem da Antiguidade Greco-Romana para a Civilização Medieval no ocidente europeu, atentando para as oscilações historiográficas produzidas nestas perspectivas em decorrência de mutações teóricas e metodológicas oriundas dos campos históricos surgidos com as novas tendências do século $\mathrm{XX}$. São discutidas aqui não apenas as teses que têm norteado a compreensão sobre o fim do Império Romano do Ocidente, como também as flutuações entre as demarcações no período de transição que conduz do mundo antigo ao mundo medieval
\end{abstract}

Palavras-chave: Antiguidade; Idade Média; Período de transição.

Delimitar um grande período historiográfico no tempo, separando-o de outro que se estende atrás dele e de outro que começa depois, é uma operação que traz indeléveis marcas ideológicas e culturais que nos falam da sociedade na qual está mergulhado o historiador, dos seus diálogos intertextuais, de visões de mundo que de resto vão muito além do próprio historiador que está estabelecendo seus recortes para a compreensão da História. Os próprios desenvolvimentos da historiografia - os novos campos históricos e domínios que surgem, a emergência de novas relações interdisciplinares, os

\footnotetext{
- Professor Doutor - Departamento de História - Programa de Pósgraduação em História - Universidade Severino Sombra - USS - 27700000 - Vassouras - RJ - Brasil. E-mail: jose.assun@globo.com
} 
enfoques a abordagens que se sucedem como novidades ou como reapropriação de antigas metodologias - trazem obviamente uma contribuição importante para que a cada vez se veja o problema da passagem de um a outro período histórico sob novos prismas.

Examinaremos sob esta perspectiva a questão da Antiguidade e de sua oscilação de fronteiras temporais em relação à Idade Média, quando se tem em vista uma periodização da História no Ocidente. Será oportuno partir da constatação de que o acontecimento fundamental que rege muito habitualmente esta fronteira - ainda que se discutindo qual o momento mais emblemático a ser considerado - é recorrentemente o fim do Império Romano ou o fim da civilização greco-romana, para considerar o problema em uma perspectiva mais ampla.

Este acontecimento - que de resto não teria maior importância para as diversas histórias possíveis de serem construídas em relação às espacialidades não-européias - busca colocar precisamente em relevo a importância do Ocidente na história do mundo. De igual maneira, aqui temos um acontecimento-demarcador que também favorece uma historiografia cristã específica, pois o mundo antigo vai cedendo lugar ao mundo medieval à medida que a Igreja Cristã vai se afirmando como força política importante, como aspecto definidor de uma nova civilização e, sobretudo, de uma nova cultura. É interessante observar, aliás, que a Antiguidade e a Idade Média são parceiras no projeto de fornecerem ao Ocidente Moderno e ao Ocidente Contemporâneo dois de seus principais traços definidores de identidade: os valores greco-romanos que futuramente se tornariam uma base para a cultura burguesa e o cristianismo, que se tornaria a religião predominante no Ocidente. Identitariamente, o Ocidente poderia ser apresentado simultaneamente como filho de Aristóteles e filho de Cristo, para falar em termos metafóricos ${ }^{1}$.

Por outro lado, se o fim do Império Romano - tomado como signo do próprio "fim do mundo antigo" - é habitualmente proposto como evento demarcatório entre os dois períodos, a 
verdade é que entre o desaparecimento do mundo antigo e a emergência da Idade Média existe uma grande zona temporal repleta de ambiguidades, por assim dizer, onde se confrontam intensamente as rupturas e permanências entre estas duas fases da História Européia. Por isso, esse grande período de alguns séculos - que alguns situam entre os séculos IV e VIII, ou mesmo entre os séculos III e VIII - tem sido perspectivado de maneira diferente pelos vários grupos de historiadores, gerando inclusive denominações distintas.

Alguns dos historiadores da Antiguidade chamam-no de "Antiguidade Tardia". Já alguns dos medievalistas preferem-no chamar de "Alta Idade Média" ou de "Primeira Idade Média". Vale dizer, muitos dos medievalistas costumam ver neste período um começo, o início de uma nova era, e incorporam-no como seu território historiográfico. Reconhecendo as permanências trazidas da Antiguidade, que só lentamente se desfazem, centram contudo o principal de suas atenções sobre as rupturas, sobre o que este período traria de singularmente novo para a História.

A posição no campo dos antiquistas é bastante dividida. Uma das dicotomias mais tradicionais - de certo modo já superada pela historiografia recente - é aquela que se estabelece no seio do grupo de historiadores que comparam a civilização greco-romana a um organismo vivo. De um lado, teremos aqueles que investem no imaginário de que a civilização greco-romana teria desaparecido abruptamente, de outro, teremos aqueles que investem na idéia de que a civilização greco-romana foi definhando ou decaindo mais ou menos gradualmente. À parte isto, já veremos, seria possível visualizar o Império Romano não como organismo vivo, e sim como algo que a partir de certo momento vai se transformando nas novas realidades civilizacionais que se afirmariam no período medieval - de um lado o Império Bizantino, de outro a civilização ocidental cristã partilhada pelos novos reinos europeus. Por fim, a visualização do Império Romano não como organismo, mas como um outro tipo de sistema complexo, permitiria examinar o seu rápido ou gradual desaparecimento, conforme a perspectiva do 
analista, como uma "desagregação" das forças que o sustentavam e que lhe davam a sua especificidade.

Do primeiro grupo de análises indicado - aquele que metaforiza o Império Romano como um grande ser vivo - tornouse célebre e emblemática a frase do historiador Piganiol ${ }^{2}$, que costumava afirmar que "a civilização romana não morreu de morte natural; foi assassinada". A grande crise econômica, política e militar do século III - marcada por intensas guerras civis - para Piganiol teria dado origem a uma nova concepção de poder imperial que se consolidaria no futuro Império Bizantino. A parte ocidental, contudo, não teria resistido aos avanços "bárbaros" - para utilizar esta expressão do próprio historiador de modo que aqui a explicação da "queda" do Império é direcionada para os fatores externos. Nesta mesma esteira, Arther Ferril ${ }^{3}$ defende a idéia de que o grande marco da queda seria o ano 476 - por ocasião da deposição de Rômulo Augusto, o último imperador romano do Ocidente, por Odoacro - o que teria contribuído decisivamente para destruição do poderio militar romano. Guardemos esta primeira posição: elas nos revelam o olhar do corte que vem de fora, da ruptura mais imediata.

Deposição de Rômulo

Augusto por Odoacro

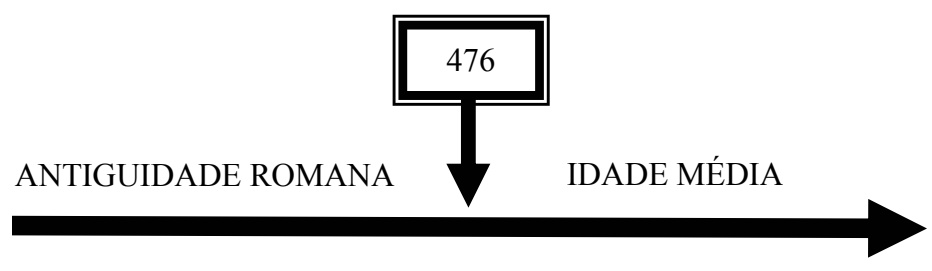

Outras datas importantes para este tipo de leitura da Passagem que privilegia os eventos bélicos podem ser buscadas nos momentos emblemáticos em que povos não-latinos saqueiam Roma, berço e símbolo máximo do poderio do Império 
PASSAGENS DE ANTIGUIDADE ROMANA AO OCIDENTMEDIEVAL:...

Romano. Neste sentido, o saque de Roma pelos Visigodos sob o comando de Alarico, em 410 d.C - vivido de maneira particularmente traumática pelos habitantes de Roma e de modo mais geral pelos cidadãos do Império nas diversas províncias -, bem como o saque de Roma pelos Vândalos em 455 d.C parecem prenunciar de uma certa ótica esse acontecimento aparentemente mais definitivo que é a Deposição de Rômulo Augusto por Odoacro, rei dos hérulos, em 476 d.C. Para a imagem, hoje bastante questionada, da "Roma assassinada pelos bárbaros", os saques visigodo e vândalo parecem funcionar como duas facadas iniciais e, de fato, pode-se dizer que de algum modo contribuíram significativamente para ferir irremediavelmente, no âmbito simbólico, a idéia de uma Roma inexpugnável. Mas daí a situar acontecimentos como esses na centralidade de um processo que por suposto teria conduzido abruptamente ao desaparecimento do mundo romano, vai uma distância maior, e, em vista de um posicionamento crítico em relação à centralidade dos acontecimentos militares que teriam promovido todo um fim de uma época, surgiram concomitantemente novas interpretações, conforme veremos mais adiante.

Por ora, vale lembrar ainda que, mesmo a leitura do "assassinato do Império Romano" permite examinar este que seria o fatídico momento ou o processo do "assassinato", se assim podemos dizer, de modo bem mais complexo, e neste caso o acontecimento das "invasões bárbaras" pode ser lido não necessariamente como um saque em destaque ou uma invasão específica, mas sim como todo um conjunto de acontecimentos relacionados às invasões ou migrações germânicas. Neste sentido, fariam parte de um mesmo "acontecimento-pacote", entre outros itens, os confrontos que se dão entre povos germânicos e romanos a partir do século III d.C, bem como eventos mais específicos, como o fato de que os godos já tinham aniquilado legiões romanas em Adrianópolis em 378 d.C, os saques visigodo de 410 d.C e vândalo de 455 d.C, fechando-se o pacote, finalmente, com a deposição de Rômulo Augusto em 476 d.C. Esses, naturalmente, são apenas alguns exemplos, e o 
"acontecimento-pacote" ao qual nos referimos engloba certamente muito mais eventos, alguns que possivelmente sequer passaram à História registrada, mas que devem ter trazido a sua contribuição atomizada para o resultado geral que em um tempo relativamente curto mudou a face da História do mundo antigo ${ }^{4}$.

Posto isto, e consideradas as simplificações e complexidades possíveis a esta primeira leitura, consideraremos agora que, em radical oposição à tese de que a civilização romana é destruída pelas invasões ou migrações dos povos germânicos, teremos os historiadores que defendem a idéia do 'Declínio do Império Romano'. Opondo-se à frase de Piganiol de que "o Império Romano foi assassinado", Ferdinand Lot $^{5}$ - um dos defensores da hipótese do declínio - propõe a frase de que "o Império Romano morreu de morte natural" 6 . Aqui, a idéia do acontecimento que produz o corte ou a ruptura definitiva, teremos a idéia do processo que conduz à "decrepitude" de toda uma civilização. O acontecimento-ruptura é aqui, ainda mais necessariamente, substituído pelo acontecimento-processo. De qualquer forma, em um caso ou outro, ainda teremos a idéia de algo que "termina", e não de algo que se "transforma". $\mathrm{Na}$ análise de Lot, as crises sociais, econômicas e políticas do século III teriam gerado uma nova resposta política assinalada por um Estado interventor, corrupto e burocratizado que substitui a antiga autoridade senatorial. A esta crise, da qual o Império Romano jamais teria se recuperado, também se somaria o novo tipo de organização militar onde os povos germânicos incorporados ao Império desempenhariam um papel cada vez mais destacado, por vezes à maneira de mercenários. Estes e outros processos são mostrados como os sintomas de um declínio ${ }^{7}$. O que é significativo, de qualquer modo, é que também nesta leitura, o Mundo Romano e o Mundo Medieval são mostrados um tanto como planetas estanques: um começa onde o outro já se foi, e são bastante minimizadas as interpenetrações entre estes dois mundos. 
PASSAGENS DE ANTIGUIDADE ROMANA AO OCIDENTMEDIEVAL:...

MUNDO ROMANO

MUNDO MEDIEVAL

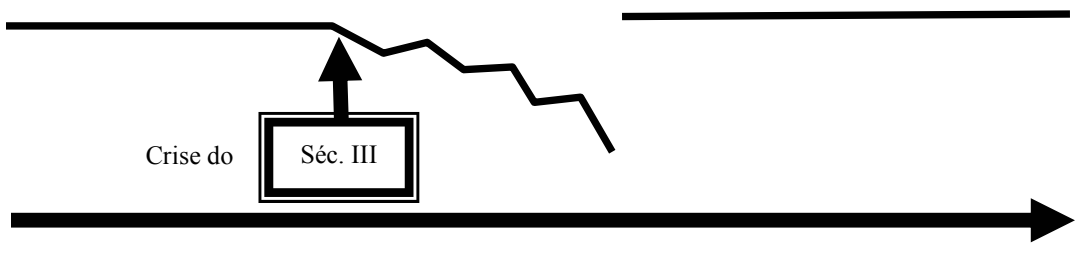

Podemos indagar sobre o que nos revela, acerca das concepções historiográficas que a sustenta, a dicotomia que permeia a idéia de que o Império Romano morre como um grande Ser, ora assassinado, ora definhando como um velho moribundo que ao final de sua vida vê esvair-se gradualmente a sua energia vital enquanto se desbotam os principais traços que lhe compunham a identidade. A idéia de um 'acontecimentoruptura' que teria presidido a morte do Império Romano através da violência dos povos germânicos se adapta, por exemplo, a uma historiografia que tem importantes desenvolvimentos no século XIX, e que anseia delimitar com precisão o 'acontecimento', situando-o por vezes em uma data bem definida, e de qualquer modo sempre enfatizando o acontecimento político - "político" no sentido antigo, do macropoder que se estabelece no nível dos grandes Estados, Instituições e confrontos militares. Ao mesmo tempo, na outra ponta da dicotomia, a idéia de "queda" ou de "declínio" amparase em muitos casos, embora por um caminho distinto, nesta mesma velha história política que se orienta tendo como perspectiva central a ser analisada a capacidade de uma civilização manter ou não uma unidade imperial mais ampla. Perder a unidade política, deste ponto de vista, é morrer, envelhecer, decair em vigor. É aliás oportuno lembrar as considerações do historiador francês Jacques Le Goff sobre as apropriações historiográficas do conceito de "decadência" - um conceito que acrescenta um tom ainda mais depreciativo à idéia de "declínio" - e que também pode eventualmente ser 
direcionado para questões meramente políticas relacionáveis à desintegração da estrutura política ${ }^{8}$. Por fim, veremos oportunamente, ao lado das idéias de "declínio", "queda", "decadência", outros conceitos têm sido propostos pela historiografia recente, como o de "desagregação", todos com implicações mais específicas ao estudo do último período do Império Romano.

Por ora, consideraremos que os desenvolvimentos modernos da historiografia sobre a passagem da Antiguidade à Idade Média correspondem precisamente à superação desta dicotomia que, apesar de gerada por posições aparentemente inconciliáveis - o assassinato ou a morte natural do Império trazem como pano de fundo um mesmo posicionamento historiográfico francamente baseado nos acontecimentos políticos no nível institucional. Com o desenvolvimento da historiografia do século XX, o olhar dos historiadores vai como que se desatrelando desta exclusividade em relação à história política de âmbito institucional, e cada vez mais novas dimensões vão sendo colocadas em cena como questões centrais passíveis de serem examinadas. Economia, Cultura, Mentalidades, Imaginário, Demografia - o surgimento de novas especialidades da história voltadas para o diálogo com estas dimensões fundamentais permitem que um mesmo conjunto de acontecimento seja beneficiado por diversificadas cronologias que dependerão do problema a ser examinado pelo historiador.

Os estudos de análise histórica de populações, por exemplo - ao instituírem a partir de meados do século XX um novo campo histórico a ser definido como História Demográfica - rechaçam por princípio a antiga maneira historiográfica de apodar de "invasões bárbaras" ao fenômeno do adentramento do Império Romano por povos diversos. Nem "invasões" e nem "bárbaras", aliás, pois duplamente tem sido revista esta antiga maneira de interpretar o movimento de gentes que iria transformar tão completamente a face do Império Romano. De fato, os modernos estudos de História Demográfica começaram a levar os historiadores a enxergarem em uma perspectiva mais ampla penetrações e migrações dos povos não-latinos - no qual a parte 
PASSAGENS DE ANTIGUIDADE ROMANA AO OCIDENTMEDIEVAL:...

das invasões seria apenas a ponta de um iceberg mais significativo a ser considerado. De outro lado, os desenvolvimentos de uma História Cultural em perfeito diálogo com a Antropologia tornavam inaceitável a segunda parte da expressão - a que permitia denominar certos povos como "bárbaros". Da mesma forma, esta mesma História Cultural, com sua revolução de novos objetos, permitiu um exame mais pertinente da interação entre as populações latinas e as populações germânicas, ao lado da avaliação de seus confrontos de alteridade. $\mathrm{O}$ encontro e o choque de culturas - mais do que o entrechoque de exércitos - podia desempenhar a partir daqui um papel mais central nas análises historiográficas.

Ainda a propósito da reavaliação da questão do impacto dos povos não-latinos sobre o Império Romano, será preciso considerar, acompanhando as interpretações historiográficas mais recentes, que na verdade os povos não-latinos (germânicos, citas) agridem ou adentram o Império de muitas maneiras, e não apenas como invasores que podem ou devem ser analisados de um ponto de vista estritamente militar. Assim, por exemplo, se tomarmos apenas como foco de análise o caso dos godos nos seus dois principais ramos - os ostrogodos e os visigodos - poderemos examinar várias nuances de adentramentos em momentos diversos, e, certamente, um grande leque formado por estas nuances ao longo de todo um processo. Os visigodos já vinham enfrentando militarmente os romanos desde 251 d.C, obtendo algum sucesso, e registram-se no decurso do século III muitas de suas incursões militares a territórios romanos ${ }^{9}$. Mas já no século IV, quando sofrem terríveis derrotas diante de contingentes hunos vindo do leste e que os massacram e empurram para o Oeste, é na qualidade de uma massa de cerca de 100.000 refugiados visigodos que eles imploram e recebem autorização do imperador romano Valente para atravessarem o Danúbio de modo a viverem dentro dos limites do Império. Ali veremos multidões famintas e amedrontadas que atravessam o Danúbio, mais do que aqueles guerreiros conquistadores que logo ficariam imortalizados na imagem do saque de Roma em 410, e é nesta qualidade de uma 
massa de refugiados que eles são acolhidos em princípios do século IV, sendo notável destacar que eles passam inclusive a serem explorados pelas autoridades romanas com impostos excessivos e condições de trabalho desfavoráveis. A exploração é tanta, aliás, que já por volta da segunda metade do século IV eles estão a ponto de se rebelarem contra o Império que os acolhera, e é agora um confronto sob esta nova perspectiva - de povos que já estavam vivendo dentro dos limites do Império e sob o jugo das autoridades romanas, e que contra estas se rebelam - que veremos o embate de 378 entre romanos e visigodos, com a vitória destes últimos na célebre e marcante batalha de Adrianópolis, onde integram um exército confederado de povos não-latinos que impõe pesada derrota ao exército imperial romano. $\mathrm{Na}$ sequência, promoveriam saques de diversas cidades em direção ao Mediterrâneo. Depois disso, com muitas negociações, os visigodos são integrados pelo exército romano - e já em 382 vemo-los estabelecidos pelo Imperador Teodósio I em uma província romana ao norte da península balcânica, onde desempenham um significativo papel na defesa daquelas fronteiras do Império até 395. E será já como exército vinculado ao Império que, mais tarde, a partir de 401, em novo movimento para o oeste, eles se insurgem, novamente se desvinculando da autoridade Romana, até que os acontecimentos conduzem ao saque visigodo de Roma, sob o comando de Alarico, em 410. A história não se encerra aí, e já em 418 veremos os visigodos se estabelecerem no sul da Gália e na Hispânia, já novamente como federados do Império, a partir de um acordo entre o imperador Constâncio e o rei Ataulfo dos visigodos. Mas em 475, já veremos um novo movimento de independência onde Eurico estabelece um reino visigodo de Tolosa, desvinculado do Império.

A síntese desta complexa trajetória dos visigodos para dentro e por dentro do Império, com encaixes e desencaixes dos povos visigodos em relação ao Império e ao sentimento de pertença em relação à cidadania romana, revela-nos desde o século III sucessivas nuances: a de opositores militares, a de refugiados, a de povos assimilados, a de povos assimilados que 
se rebelam, a de contingentes militares integrados ao Império, a de contingentes integrados ao exército imperial que novamente se insurgem, para retornar então à nuance de opositores militares. Além disso, deveríamos verificar ainda a nuance sempre presente de populações de visigodos que poderiam ser vistas simplesmente como migrantes, como grandes massas populacionais que encontram oportunidade de se deslocar para terras romanas em busca de melhores condições. $O$ congelamento de rios como o Reno, em certos invernos como o de 406, pôde oferecer em certos momentos uma ponte natural para populações de povos não-latinos que, do outro lado do rio, só poderiam concretizar este deslocamento massivo com o apoio deste providencial fato da Natureza. Por outro lado, ao longo de toda a História do Império Romano, contingentes menores ou maiores de migrações bárbaras forçaram as fronteiras do Império como um fato que sempre fora bem administrado. No conjunto dos migrantes, novas nuances se desenhavam, de salteadores que chegavam e partiam a homens em procura de trabalho que se estabeleciam, a guerreiros que conseguiam ser assimilados no próprio exército romano. Percebemos, portanto, as mais distintas nuances acompanhando os deslocamentos visigodos - e de outros povos germânicos de modo geral - para dentro do Império e por dentro do Império, o que não permite falar apenas, taxativamente, de "invasões visigodas", ou também de "invasões bárbaras" para os outros casos. A História Demográfica, a História Social, a História Cultural - com seus extraordinários desenvolvimentos historiográficos a partir do século XX - permitiriam aliás examinar estes processos migratórios e estes grandes deslocamentos a partir de novas perspectivas, para além da perspectiva que era antes proporcionada pela História Militar.

Antes de avançarmos em um quadro mais diversificado de perspectivas sobre a Passagem, será útil ainda lembrar que - em que pese o fato de que tenha sido a História Política do século XIX que grosso modo favoreceu certas leituras sobre o papel das "agressões externas" ou do "declínio interno" na "morte" ou "queda" do Império Romano - diversas destas interpretações já 
vinham sendo colocadas até mesmo desde a própria época da Passagem da Antiguidade para o período Medieval. Acontecimentos como o saque visigodo de Roma em 410 impactaram tanto os cidadãos do Império que, tão logo ocorreram, produziram imediatas interpretações sobre estes acontecimentos, a exemplo das inquietações expressas nas Epístolas de São Jerônimo. No âmbito cristão, inclusive, começavam a surgir algumas interpretações de cunho milenarista que queriam pressentir, nos surpreendentes acontecimentos que assolavam o Império, a proximidade do fim do mundo. Em contrapartida, havia os que enxergavam nas transformações religiosas do Império, consolidando-se na adoção do Cristianismo como religião única, a verdadeira origem das calamidades que agora se abatiam sobre a civilização romana, de modo que para salvar esta civilização seria preciso reverter ao paganismo. Por fim, havia os que viam as invasões germânicas e hunas como um brutal acontecimento que estava prestes a soterrar a civilização.

Desta forma, diante das diversas avaliações produzidas na própria época sobre o fim do Império Romano como decorrente das invasões de povos não-latinos, e também das avaliações sobre o declínio do Império como decorrentes da corrupção dos costumes, ou mesmo diante da consideração de pretensos desdobramentos negativos que se julgava que deveriam ser creditados à adoção do Cristianismo como religião oficial do Império, pode-se dizer que estas interpretações produzidas na própria época não deixam de ser precursoras de posições historiográficas que se fortaleceriam depois.

Os saques de Roma e a crise do fim do Império, enfim, ofereceram-se como verdadeira arena para combate intelectual entre defensores do Paganismo ou do Cristianismo que desejavam culpar o campo oposto pelos eventos mais alarmantes que iam se produzindo no Império. As várias posições possíveis encontraram argutos defensores. Já Montesquieu, em suas Considerações sobre as causas da Grandeza dos Romanos (1734) ${ }^{10}$, ilustrava esta pequena arena de idéias que se organizara na própria época dos acontecimentos 
PASSAGENS DE ANTIGUIDADE ROMANA AO OCIDENTMEDIEVAL:...

mais traumáticos do último Império Romano citando as mencionando exemplos das três posições clássicas: Orósio, Salviano e Agostinho. Assim, enquanto Orósio busca situar-se em uma posição de certa neutralidade no debate entre o Cristianismo e Paganismo, escrevendo uma História para provar que em todos os tempos existiram desgraças tão grandes quanto aquelas de que se queixavam os pagãos, já Salviano comporia uma obra - intitulada Do Governo do Mundo - para sustentar a idéia de que os desregramentos do cristãos é que haviam atraído as invasões bárbara ${ }^{11}$.

A posição de Santo Agostinho ${ }^{12}$ foi bem singular. Interessado em livrar o Cristianismo de qualquer acusação ou responsabilidade pela queda do Império - já que à sua época autores pagãos insinuavam ou argumentavam bastante abertamente que a sujeição de Roma por povos pagãos eram claros sinais de que o Império estaria sido punido pelos deuses por sua adoção do Cristianismo - ocupa-se em trabalhar com a idéia de um "declínio" que teria sido provocado precisamente pela corrupção dos costumes pagãos, que de acordo com sua argumentação, já viria de tempos anteriores. A concretização maior desta argumentação - a par de uma extensa tentativa de demolir a filosofia não-cristã e todas as críticas ao Cristianismo foi a obra intitulada Cidade de Deus (2000), e nela a tese de um declínio da civilização romana herdada dos tempos do paganismo encontra um grande resguardo ${ }^{13}$.

As duas posições, exemplificadas à própria época pelo contraste entre Salviano e Santo Agostinho, seriam retomadas constantemente em épocas posteriores - a do "abate externo" (com ou sem a punição de Deus ou dos deuses) ou a do "declínio interno" - e a interpretação de Maquiavel pode ser evocada como um exemplo de análise que novamente coloca os ataques "bárbaros" na centralidade do processo. Gibbon, por outro lado, já escrevendo em $1776^{14}$, reformula a seu modo a idéia de um declínio interno, e sugere em certas passagens que o "abuso do cristianismo" teria exercido um papel considerável no declínio do Império, embora procure formular também a hipótese de que 
o declínio de Roma teria sido consequência natural e inevitável de sua desmedida grandeza ${ }^{15}$.

Conforme se vê, as posições de que os fins do Império Romano estão relacionados ora às agressões e penetrações dos povos não-latinos, ora a fatores internos - que podiam ir desde aspectos sociais a religiosos - foram recorrentes em um longo período que principia à própria época dos acontecimentos mais marcantes que anunciaram a queda ou o declínio do Império Romano. Essas posições, de lado a lado, atingem os séculos XIX e XX com a célebre querela sobre o "assassinato" ou a "morte natural" do Império Romano. Mas logo abririam espaço para outras proposições, mais tendentes a enxergar a transformação de um período em outro do que o fim taxativo de um grande período da História. Estas novas proposições, naturalmente, são beneficiadas precisamente pela multiplicação de novos campos históricos, para além da História Política tradicional.

A emergência de campos históricos enfatizando a Economia e as relações sociais, por exemplo, abre um certo conjunto de possibilidades e de novas leituras possíveis, inclusive permitindo novas periodizações. Uma História Econômica ou uma História Social do Império Romano, por exemplo, impõem cada qual o seu conjunto de recortes que em nada coincidirá com o conjunto de recortes produzidos pela História Política do tipo que era tradicionalmente realizado no século XIX. Seja no âmbito dos historiadores marxistas do século $X X$, seja no âmbito dos historiadores que são influenciados pela abordagem Econômica e Social da primeira fase dos Annales, surgem aqui novos modelos narrativos e analíticos que geram as suas próprias periodizações.

Apenas para citar o âmbito das análises marxistas, outros serão os acontecimentos processuais que deverão ajudar a compreender a passagem da Antiguidade à Idade Média. Surgem aqui novas possibilidades, considerando as duas definições da História propostas por Marx - de um lado a de que a História é a "história da transformação dos modos de produção", e, de outro, a idéia de que a história é a "história da luta de classes". Para o caso do estudo da passagem da 
civilização romana para as civilizações medievais, impõe-se de um lado o acontecimento-processual da superação do modo de produção escravista em um Império que nos seus limites já não consegue conservar a acumulação de mão-de-obra escrava; de outro lado, destacam-se as crises sociais do século III como acontecimentos fundamentais. Conforme a análise marxista em questão centre sua atenção mais na ultrapassagem do 'modo de produção' ou da 'luta de classes', tem-se a possibilidade de matizes diferenciados dentro da análise da história da passagem da antiguidade romana à medievalidade ocidental, segundo a abordagem oferecida pelos princípios do materialismo histórico. Apenas para citar dois exemplos, indicaremos as análises de Staerman $^{16}$ e de Perry Andersen ${ }^{17}$.

Seria possível citar também como exemplo de análise que traria a primeiro plano a Economia em sua relação com a Sociedade a avaliação de Max Weber sobre a passagem da Antiguidade à Idade Média ${ }^{18}$. Também considerando importante as transformações no regime de trabalho e exploração econômica - e avaliando tanto o colapso do sistema escravista como o surgimento de uma economia natural - Weber concede uma atenção especial à passagem de uma civilização essencialmente urbanizada para uma civilização que vai se ruralizando nos seus aspectos essenciais. Esta consideração de que o traço essencial da antiguidade clássica é a combinação de escravismo e urbanização leva Weber a examinar atentamente o desaparecimento gradual do comércio local e de longa distância, já desde fins do século II.

É também uma explicação e uma periodização atenta aos movimentos comerciais a que nos apresenta o medievalista belga Henri Pirenne (1935-1937) ${ }^{19}$. Desenvolvendo uma tese que posteriormente não deixou de desencadear muitas críticas, Pirenne destaca como acontecimento mais relevante no processo de estabelecimento da Idade Média um processo aparentemente político, mas que na verdade tem a sua importância precisamente em virtude dos efeitos econômicos que desencadeia. $O$ grande divisor de águas, para o historiador belga, é o acontecimento da Expansão Islâmica no século VIII, 
precisamente porque, segundo a sua análise, o domínio islâmico do Mediterrâneo ocidental não apenas quebrará uma unidade mediterrânica que teria caracterizado a Europa até o século VIII, como porque ao fazer isso, rompem-se os caminhos comerciais que sustentavam até então a vida material do ocidente europeu, forçando o deslocamento do eixo político-geográfico da nascente civilização do ocidente medieval para o centro da Europa. Carlos Magno - representando o mundo carolíngio - surge na sua análise como o inevitável contraponto histórico de Maomé signo da expansão islâmica.

Se o diálogo mais intenso com a Economia permitiu o surgimento de novas análises e organizações cronológicas da passagem da Antiguidade Romana à Medievalidade Européia, o século XX também trouxe uma atenção especial a questões direcionadas para a percepção da psicologia do homem, para o estudo das mentalidades, para o exame da vida cotidiana. $O$ mesmo movimento de expansão que permitiria que surgisse uma Psico-História, uma História das Mentalidades, uma História do Cotidiano, e tantos novos domínios - também permitiu que novas dimensões fossem priorizadas pelos historiadores deste período que permeia a passagem da Antiguidade à Idade Média.

Com isto, permite-se cada vez mais que sejam vistos como períodos dotados de suas próprias singularidades tanto o período do Baixo Império Romano - examinado não mais como um período de decadência - como o período que se situa entre a extinção política do Império Romano do Ocidente no século V e a expansão islâmica no século VIII. Atentando para uma importante questão associada à psicologia social, o historiador Peter Brown constrói sua explicação para o Fim do Mundo Antigo $^{20}$ - destacando neste caso o período do Baixo Império entre os séculos III e IV - a partir de uma análise que ressalta como acontecimentos mais relevantes a 'cristianização do ocidente' e a transformação político militar a partir dos exércitos romanos das províncias (240 d.C). Para o primeiro fator - um aspecto ligado a transformações psicológicas presentes na sociedade - Brown destaca o surgimento no homem comum da 
PASSAGENS DE ANTIGUIDADE ROMANA AO OCIDENTMEDIEVAL:...

necessidade de um deus intimista. Esta mesma necessidade, que ampara na sociedade mais ampla a cristianização do mundo antigo, daria origem também ao Monacato, que posteriormente viria a se desenvolver como uma importante alternativa característica da religiosidade medieval.

Sugerindo uma periodização algo diferenciada, Henri Marrou (1980) ${ }^{21}$ propõe-se a examinar o período que envolve a passagem da Antiguidade à Medievalidade considerando questões também ligadas à psicologia e à cultura, mostrando-se particularmente atento aos desenvolvimentos estéticos como sinais importantes para a compreensão das singularidades de um período no qual - além das transformações - as permanências não devem ser esquecidas como importantes elos que conduzem a história. A sua organização cronológica delineia um período entre os séculos III e VI, para o qual a fusão da cultura pagã com os valores cristãos adquire aqui um destaque particularmente significativo, ao lado do surgimento de novas concepções religiosas e estéticas. Ao mesmo tempo, ao encaminhar uma análise que considera as inovações mas também está atenta para as permanências, Marrou é o primeiro historiador a introduzir um novo conceito na periodização da história da civilização ocidental: o de "antiguidade tardia". Outros autores retomariam este conceito, permitindo-se variar os limites inicial e final deste período que passaria a ser reivindicado como território historiográfico tanto pelos historiadores da Antiguidade como pelos historiadores da Idade Média $^{22}$.

As idéias de nomear este período limítrofe como 'Antiguidade Tardia' ou como 'Idade Média Primitiva' caminham juntas, ambas com direito a legitimidade no universo das possibilidades historiográficas. Conforme se olhe para o período com vistas à compreensão dos desenvolvimentos terminais da Antiguidade, ou com vistas à compreensão dos novos processos que mais tarde se consolidariam como tipicamente medievais, teríamos uma possibilidade ou outra. O 'período limítrofe', aqui considerado, pode-se apresentar como "disputa de território" entre historiadores da Antiguidade e da Idade Média, mas 
também pode se apresentar como espaço de diálogo, como lugar onde antiquistas e medievalistas se encontram para intercambiar suas idéias e experiências.

De todo modo, a tendência da historiografia de, a partir do século $\mathrm{XX}$, conforme se vê, foi a de permitir múltiplas leituras do fenômeno da passagem da Antiguidade a Medievalidade - aliás, considerando criticamente os limites espaciais e historiográficos destas expressões. De qualquer modo, a multiplicação de leituras deste período limítrofe entre o que se convencionou chamar de duas eras bem diferenciadas mostra-se interferida por uma profusão de novas perspectivas que na historiografia contemporânea introduzem uma miríade de novos campos históricos, como a História Social, a História Econômica, a História Cultural, a História das Mentalidades, a História Demográfica, bem como novas abordagens definidas por campos históricos que vão da História Serial à Micro-História. Esse enriquecimento de novas perspectivas, aliado à idéia de que a história desenvolve-se através de uma polifonia de temporalidades - tem permitido aos historiadores contemporâneos perceberem cada vez mais claramente que não podem existir periodizações fixas e inflexíveis, já que os diversos problemas a serem examinados é que definem cada qual a sua periodização.

Vale ainda lembrar que - no contexto dos cada vez mais estreitos diálogos interdisciplinares que se vão desenvolvendo na historiografia contemporânea - aportes diversos no âmbito teórico também têm permitido reequacionar a passagem da Antiguidade à Medievalidade como fenômeno extremamente complexo. A idéia de que teria ocorrido uma ruína ou desagregação do Império Romano em todos os seus níveis de organização, e não apenas no âmbito político, com a consequente reorganização de elementos para a constituição de um novo sistema, tem sido proposta também por historiadores que buscam amparar suas análises na Teoria da Complexidade. Aborda-se, aqui, a possibilidade de considerar o Império Romano como um 'sistema adaptativo complexo', que entra em crise quando seus diversos componentes estruturais já não 
PASSAGENS DE ANTIGUIDADE ROMANA AO OCIDENTMEDIEVAL:...

respondem com precisão e na mesma proporção ao princípio agregador do sistema ${ }^{23}$. A idéia de "desagregação" confronta-se aqui aos conceitos ou idéias mais antigas como "declínio", "queda", "decadência".

Um sistema adaptativo complexo deve ser entendido como um sistema formado por um grande número de subsistemas, elementos, agentes individuais, além de estar sujeito a inúmeras linhas de força, notando-se que o sistema converge para um certo padrão de comportamento (um "atractor") ${ }^{24}$. A noção de 'sistema adaptativo complexo', nestes casos, tem levado os historiadores a dialogarem com um antigo conceito já bem conhecido e operacionalizado pela historiografia moderna - o de "sistema" - e mais particularmente ainda com a idéia mais recente de um sistema que vai se formando naturalmente, por ajustamentos entre seus vários elementos, progredindo em sua tendência a auto-organizar-se, favorecendo a agregação de elementos já existentes e a invenção de outros, adaptando-os a uma dinâmica própria e constituindo-os como um conjunto equilibrado, até o momento em que tudo começa a se desagregar novamente.

A auto-organização permite que a ordem possa emergir do Caos, ao qual se voltará posteriormente. Conforme esta perspectiva, boa parte dos sistemas tendem a se constituir de forma complexa para, posteriormente, desintegrarem-se, de modo que a aplicação deste campo nocional à compreensão dos últimos períodos da historia da Antiguidade Romana permitiria evocar aqui a noção de "desagregação", mais do que as de "declínio", "queda" ou "decadência". A desagregação do Império Romano do Ocidente - uma vez que no Oriente Bizantino a experiência imperial seguiria mais adiante com novos elementos e com novos padrões de interação e relacionamento entre estes elementos - corresponderia à desestruturação de certo padrão (complexo) de comportamento que pode ser identificado como característico do sistema de civilização típico do Império Romano. Esse padrão de comportamento específico e particular para o qual converge cada um dos mais diversos sistemas, e que é certamente singular para cada um destes 
mesmos sistemas, corresponde àquilo que alguns teóricos da complexidade chamam de "atractor" 25 , uma espécie de "ordem" que se apresenta como dimensão de convergência do sistema, assegura-lhe o funcionamento de uma determinada maneira, e, se for o caso, um crescimento equilibrado.

No caso do sistema sócio-político-econômico-cultural que aqui estaremos chamando simplificadamente de Império Romano, diversos elementos teriam concorrido para a manutenção da ordem e para o funcionamento do sistema, integrando os diversos subsistemas e elementos em uma ordem maior, em equilíbrio dinâmico que atinge a sua expressão máxima no período da pax romana, simbolicamente o momento em que o poder do Império é inconteste, ou que assim se coloca para aqueles que o vivenciam dentro e fora dos limites do Império. O Exército, naturalmente, desempenhava um papel fundamental na manutenção da ordem, no fortalecimento dos mecanismos de identidade, na salva-guarda dos limites políticogeográficos do Império, na construção de unidade política com a qual todos os cidadãos romanos podiam se identificar e nela se verem incluídos. Outros elementos, os mais diversos, da divisão de trabalho ao sistema de educação compunham o sistema, de maneira integrada.

A história da ultima fase do Império Romano, de acordo com uma perspectiva amparada na complexidade, é a história da "desagregação", não necessariamente sob o signo de "decadência" ou "declínio" - embora estas noções não sejam necessariamente incompatíveis com possíveis interpretações que trabalhem com a noção de 'sistema adaptativo complexo' mas, em todo o caso, a história de uma rearrumação, de uma desestruturação da ordem que envolve diversos fatores.

É bastante interessante notar que um dos sintomas da desagregação, em um sistema complexo deste tipo, está precisamente na necessidade de se estabelecer controles vários sobre os diversos elementos e subsistemas que, na situação de equilíbrio natural, tenderiam a se articular e a interagir sem a necessidade de excessivas medidas de força, para além dos limites habituais assumidos pelas medidas de força nos 
momentos de equilíbrio. Em uma palavra, em um sistema como o do Império Romano, um sintoma relevante do período de desagregação está precisamente no surgimento da necessidade de várias medidas extraordinárias de força, de modo a impor uma coesão que não estava ocorrendo mais entre diversos elementos que deveriam estar articulados para assegurar a unidade do Império.

Historicamente, o século III representa um momento emblemático em que a desorganização começa a se fazer notar nos âmbitos econômico, político e militar, evocando a necessidade de medidas de força para tentar assegurar uma coesão que começava a ser ameaçada por distúrbios diversos, em um nível de ocorrência para além do que há muito já fazia parte do previsível no sistema político-social vigente. Afora os conflitos sociais diversos, bem como os distúrbios ocasionados pela crise do Escravismo, o crescente confronto entre o poder do Imperador e o Senado são sinais e desdobramentos da desorganização do sistema. A partilha do poder imperial, prenunciando a divisão do Império em duas unidades políticas onde o título imperial passará a ser hereditário, constituirá outro desdobramento, acompanhado pelo crescente poder absoluto dos imperadores - signo maior das medidas de forças autoritárias e controladoras que precisam ser agora impostas em favor da coesão do sistema.

A quebra da unidade do Exército através de um decreto imperial no século IV, criando divisões por províncias e territórios de atuação, segue-se como desdobramento da tentativa de resguardar o poder do Imperador diante de um poder muito forte concentrado em um exército unificado, mas ao mesmo tempo a medida em médio prazo incorpora-se aos fenômenos de desagregação e de formação de estruturas autônomas. Da mesma forma, a criação e imposição de castas profissionais em fins do século IV nada mais indica do que a necessidade de fazer frente a tendências de desorganização no âmbito econômico.

A antiga ordem imperial, enfim, apesar de todas as medidas de força que tentam impor a coesão, vai cedendo à HISTÓRIA, São Paulo, 28 (1): 2009 
inevitável desestruturação, a uma desagregação dos elementos que, antes coesos, conformavam a ordem do sistema. Contra tudo isto, o Cristianismo, organizando em Igreja e gerando os seus próprios padrões de espacialização política, começa a constituir um sistema paralelo, que agrega em dioceses o espaço sócio-religioso propondo uma nova organização administrativa, ora superposta ora desencaixada em relação à administração imperial. Decisivamente, a idéia de universalidade que antes residia no Império vai se deslocando para a Cristandade consolidada institucionalmente na Igreja, e este confronto entre dois projetos universais - na vida política ou imaginária - em breve se estenderá pelos séculos posteriores como uma longa reminiscência do jogo de encaixes e desencaixes entre os dois sistemas. Mas o novo mundo medieval, efetivamente, tenderá a se organizar em torno da Igreja Cristã, o que já representa um novo sistema em construção.

A avaliação da passagem da Antiguidade à Idade Média de acordo com a perspectiva da desagregação de um sistema adaptativo complexo, enfim, impõe uma nova forma de visualidade para este período de transição que precede o mundo medieval - uma espécie de granulação, onde é difícil dizer onde termina um mundo e se inicia o outro, seria uma imagem adequada para se descrever este território pleno de ambiguidades, de desconstruções e reconstruções, de desagregação e reorganização de antigos elementos ao par de novos elementos que, imperceptivelmente, parecem se ajustar de novas maneiras para a formação de um novo sistema de civilização. Estamos aqui em um território difícil de ser racionalizado, onde os fatos políticos, por mais emblemáticos e impactantes que tenham sido para seus contemporâneos e para os historiadores que posteriormente os examinaram, devem ser vistos, sobretudo, como sintomas de transformações que se iam operando nesta complexa passagem de um mundo a outro. Sobre esta vasta rede de transformações uma nova ordem emergia do caos. 
PASSAGENS DE ANTIGUIDADE ROMANA AO OCIDENTMEDIEVAL:...

A partir do contraste entre os posicionamentos historiográficos citados neste ensaio, buscou-se colocar em discussão a complexidade que se relaciona aos aspectos vários que costumam ser apontados como traços importantes para esse período que permeia a transição do mundo antigo para o mundo medieval. De um lado, devemos considerar que a maneira pela qual olhamos para um período histórico - como um começo ou um fim - já contribui de antemão para trazer uma determinada caracterização ao período imaginado. Isto de fato tornou possível considerar esta zona que se interpõe entre o fim do Império Romano e o Período Medieval como um fim ou como um começo. $\mathrm{E}$, dependendo de uma posição ou outra, permite falar-se em uma "antiguidade tardia", em "declínio do mundo romano", em uma "alta Idade Média", ou em uma "primeira Idade Média".

Em segundo lugar, como se viu, há sempre a questão da escolha dos limites que definiriam historiograficamente um período ou outro. Entre os acontecimentos processuais e pontuais escolhidos, os diversos recortes para a análise de um problema específico tornam-se possíveis. Do acontecimento-processo que se organiza em torno do esgotamento do modelo escravista, desde o século II, até as crises sociais que impõem um novo arranjo político no século III, ou até os marcos mais emblemáticos das invasões germânicas, mas também considerando este outro acontecimento-processo que seria a gradual penetração e fusão dos povos germânicos com as populações romanas, sucedem-se as possibilidades de recortar um início para o período limítrofe. Da mesma forma, entre os séculos VI e VIII - marcados pela impactante expansão islâmica - ou até mesmo estendendo-se até o século XI para questões mais específicas como a da Educação e a da Religiosidade, aqui se apresentam as variadas possibilidades de fins para este complexo período que ora é chamado de "Antiguidade Tardia", ora de "Alta Idade Média", ora de "Primeira Idade Média". Por fim, pode-se investir também na complexidade granulada que, à parte os sintomas mais evidentes que se expressam sob a forma de eventos pontuais, dificulta periodizações mais definidas. 
Eis aqui um mundo de possibilidades, extraordinariamente enriquecido pela profusão de campos históricos que beneficiou a historiografia contemporânea de modo que os historiadores pudessem examinar não apenas a Política como também a Cultura, a Economia, as Mentalidades, a Demografia, a Cultura Material, o Imaginário - fora uma enorme variedade de novos domínios temáticos abertos aos historiadores e de novos aportes teóricos que têm se colocado à sua disposição.

BARROS, José D'Assunção. Passages from Roman Antiquity to the Middle Ages: historiographic lectures of a transition period. História, v.28, n.1, p.547-574, 2009.

\begin{abstract}
This article aims to examine some interpretations and perspectives which can be or have been examined with regards to the question of the transition period from Greco-Roman Antiquity to the civilizations of the Middle Ages within Western Europe. It also tries to show the historiographic oscillations produced in these perspectives in consequence of the theoretical and methodological changes in the historiographic fields arising from the new tendencies of the $20^{\text {th }}$ century. The discussion at hand covers not only the theses which have guided the understanding of the end of the Western Roman Empire, but also deals with the fluctuations among the limits in the transition period that leads from antiquity to the medieval world.
\end{abstract}

Keywords: Antiquity; Middle Ages; Transition period.

\title{
NOTAS
}

${ }^{1}$ Vale lembrar que, em meados do século $\mathrm{XX}$, sob o contexto da emergência de novas forças dominantes na economia e na política internacional (EUA, URSS, Japão) e da descolonização na Ásia e África, surgem as primeiras análises pós-colonialistas sobre a História da Roma Antiga de uma perspectiva não mais eurocêntrica. Ver autores como BADIAN (BARDIAN, E. Roman Imperialism in the Late Republic. 
PASSAGENS DE ANTIGUIDADE ROMANA AO OCIDENTMEDIEVAL:...

Oxford: University Press, 1968) e VEYNE (VEYNE, Paul. Y-a-t-il eu un imperialisme romain?. Mélange de l'École Française de Rome Antiquité. 87 :793-855, 1975).

${ }^{2}$ PIGANIOL , A. L'Empire chretien. Paris: Hier, 1972, p.466.

${ }^{3}$ FERRIL, A. A Queda do Império Romano. Rio de Janeiro: Jorge Zahar, 1989.

${ }^{4}$ Vale lembrar que essa percepção do impacto dos povos extraromânicos como um grande processo já é antiga. Nas Considerações sobre as causas da Grandeza dos Romanos, escritas por Montesquieu em 1747, já iremos encontrar a seguinte passagem: "Não foi uma determinada invasão que destruiu o Império, mas todas as invasões. Depois da que foi muito generalizada no reino de Galo, ele pareceu restabelecer-se, pois não havia perdido terrenos. Entretanto, paulatinamente, deslizou da decadência para a queda, até ser subitamente prostrado no reinado de Arcádio e de Honório" (MONTESOUIEU. Considerações sobre as causas da Grandeza dos Romanos. Rio de Janeiro : Contraponto, 2002, p.158). É interessante já identificar a presença do contraste entre os conceitos de "decadência" e "queda" em Montesquieu, em um texto que precede a célebre Análise de Gibbon algumas décadas depois. Merece destaque também a percepção do processo como sujeito a pequenas idas e vindas, apesar do paulatino caminho para o inevitável colapso.

${ }^{5}$ LOT , Ferdinand,. Fim do mundo antigo e início da Idade Média, Lisboa: Edições 70, 1985.

${ }^{6}$ Além de Lot, outro autor que acompanha esta linha interpretativa é A. H. Jones, com seu livro intitulado Declínio do Mundo Antigo (JONES, A. H. M. Déclin du Monde Antique. Paris : Sirey, 1970).

7 Sintetizaremos um conjunto de fatores que podem ser pontuados como desdobramentos importantes da Crise do século III: Empobrecimento da população gerando confrontos sociais; Desmonetarização e crescimento da economia natural; · Centralização do poder imperial, em detrimento da antiga autoridade senatorial; Petrificação da sociedade em segmentos bem definidos; Burocratização e militarização do poder; • Intensificação de exigências fiscais; - Penetrações dos povos "bárbaros"; - Desenvolvimento de um novo sentimento religioso. Sobre a crise do século III e seus efeitos, ver FERNÁNDEZ URBINA, La crisis del siglo III y el fin del Mundo Antiguo. Madrid: Akal, 1982. 
${ }^{8}$ LE GOFF, Jacques. "Decadência e progresso/reação". In: ROMANO, R. (org.). Enciclopédia Einaudi; memória/história. Lisboa: Imprensa Nacional-Casa da Moeda, 1984. p.416.

${ }^{9}$ Registram-se incursões godas nas províncias romanas da península Balcânica, e entre 270 e 275 chegam a impor aos romanos o abandono das terras da Dácia, que passam a ocupar. São precisamente os godos que vivem entre os rios Danúbio e Dniester que passam a receber a denominação de "visigodos". Enquanto isso, os godos pertencentes a um outro ramo, estabelecido na Ucrânia, passariam a ser chamado de "ostrogodos".

10 MONTESQUIEU. Considérations sur les causes de la grandeur des romains et leur décadence, 1734. [Considerações sobre as causas da Grandeza dos Romanos. Rio de Janeiro : Contraponto, 2002].

${ }^{11}$ Ver a referida passagem em MONTESOUIEU, op.cit., p.158.

${ }^{12}$ AGOSTINHO. Cidade de Deus. Lisboa: Calouste Gulbenkian, 2000.

${ }^{13}$ Cidade de Deus (De civitate Dei contra paganos) foi escrita entre 413 e 426 em 22 livros, e sua elaboração foi essencialmente motivada como uma resposta às agressivas críticas que vinham sendo veiculadas pelos habitantes pagãos de Roma à adoção do Cristianismo como culto único permitido no Império, conforme o edito de Teodósio I em 391. Com a pilhagem de Roma por Alarico em 410, estava a ponto de eclodir uma revolta entre os romanos não cristãos, para os quais aquilo que eles consideravam como uma "invasão bárbara" seria uma resposta dos deuses pagãos ao abandono de seu culto pelo povo romano, e é neste contexto histórico que Santo Agostinho busca retratar a Cidade de Deus como uma cidade eterna e imortal que todo cristão deveria buscar para a morada eterna, em franca contraposição à cidade terrestre, transitória e sujeita às ambições humanas. Para sustentar sua defesa do cristianismo e a concomitante crítica do Paganismo como fonte de corrupção e decadência dos costumes, Agostinho empreende uma longa e sistemática análise das teorias pagãs e platônicas.

${ }^{14}$ GIBBON, Edward. Declínio e Queda do Império Romano. São Paulo: Companhia das Letras, 1989

${ }^{15} \mathrm{Um}$ pouco anterior à obra de Gibbon, mas tocando em alguns pontos comuns, são as já mencionadas Considérations sur les causes de la grandeur des romains et leur décadence, escritas por Montesquieu em 1734.

${ }^{16}$ STAERMAN, E. M., "La caída de régimen esclavista" in ARCINIEGA, A. M. P. La transición Del esclavismo al feudalismo. Madri: Akal, 1976. 
PASSAGENS DE ANTIGUIDADE ROMANA AO OCIDENTMEDIEVAL:...

17 ANDERSEN, Perry. Passagens da Antiguidade ao Feudalismo. São Paulo: Brasiliense, 2000.

${ }^{18}$ WEBER, Max., "As causas sociais do declínio da cultura antiga" in ARCINIEGA, A. M. P. La transición Del esclavismo al feudalismo. Madri: Akal, 1976.

19 PIRENNE, Henri., Maomé e Carlos Magno. Lisboa: Edições Dom Quixote, s.d. [orig: 1935-1937]..

${ }^{20}$ BROWN, Peter, o Fim do Mundo Antigo, Lisboa: Verbo, 1971.

21 MARROU, Henri, Decadência Romana ou Antiguidade Tardia?, Madri: Rialp, 1980.

${ }^{22}$ Para uma discussão sobre o conceito de "Antiguidade Tardia", ver MARTIN, P. "Ou'est-ce que l'Antiquité "Tardive"? Réflexions sur un problème de périodisation". In: CHEVALLIER, R. (ed.). Aiôn - le temps chez les romains. Paris: Picard, 1976.

${ }^{23}$ Sobre a possibilidade de examinar o Império Romano em sua fase terminal como sistema complexo que se desagrega, ver GARCIA, Gilberto Gonçalves. A Desintegração da República Romana como Ordem na Desordem. Revista da FAE, vol.4, n², 2006. Para um posicionamento conceitual acerca da Teoria da Complexidade, ver STACEY, Ralph D. Complexity and creativity in organizations. San Francisco: Berrett-Koehler, 1996).

${ }^{24}$ Para exemplificar, podemos considerar uma revoada de pássaros como um sistema adaptativo complexo no qual, de modo a não se chocarem uns com os outros nos seus vôos individuais, o conjunto de pássaros termina por constituir uma formação ordenada.

${ }^{25}$ STACEY, op.cit. p.54.

Artigo recebido em 01/2009. Aprovado em 03/2009

HISTÓRIA, São Paulo, 28 (1): 2009 